\title{
India-US Relations Through the Lens of Cold War: The Time of Estranged Relations (Brief Overview)
}

\author{
R.D. Nisar \\ Central China Normal University \\ 152, Luoyu Road, Wuhan, Hubei, People's Republic of China, 430079
}

\begin{abstract}
This paper provides a brief description of the estranged relations, ideological differences, divergences in national interests, initial misunderstandings and ups \& down in the relations between two democracies - India and the US - during the Cold War period. After the WWII, an ideological clash dubbed "Cold War" started between two competing powers: the US and the USSR. During the Cold War era, both states went at great lengths to expand their ideologies into the Asian region and its periphery. The US formed security blocs and provided substantial financial aid to Asian countries in an attempt to contain the expansion of communist ideology of its main rival (the USSR) in the Asian region. After India gained independence, the US pressured the Indian leadership into joining the US bloc against the communist Soviet Union. On the other side, the USSR built Warsaw Pact and tried to enroll the newly born states, such as India and Pakistan, in its bloc to counter the US course of action. However, India was not disposed to join any blocs, the US bloc above all, and entered the Non-Alignment Movement. The Indian leadership supported the catchphrase "Asia for Asians" and condemned the involvement of extra-regional powers, such as the US, in Asian regional matters.
\end{abstract}

Keywords: Cold War, India-US estranged relations, India \& Non-Alignment Movement, US policy of containment

\section{India-US Relations During the Cold War: Time of Estrangement}

The independence of India was declared on 15th August, 1947, at a time when the world was on the verge of division into two blocs (the USA \& the USSR) and the menace of the Cold War was looming on the horizon of the postworld-war world. Initially, the newly emerged state India could not afford to show any particular inclination to joining either bloc and followed the policy of NonAlignment: a policy of peaceful co-existence. Strong commitment to democratic values and norms gave India and the US a common ground, however, India's join- 
ing the Non-Alignment Movement alienated the two countries, as the US leaders took it to be an unfriendly gesture by the country. Indian policy of Non-Alignment and affable disposition towards China upset Americans policy makers. Propagating their ideologies and different ways of living, the US and USSR formed security alliance pacts, such as NATO, SEATO, and Warsaw Pact, to counter each other's game plan. India, in its turn, preferred to stay away from all security pacts and chose a neutral stance [1]. Despite the US efforts to coerce India into an alliance, India held on to its position of non-interference. As Nehru put it, "India wants World Peace rather than to join any bloc". By adopting the non-alignment policy, India managed to ward off both power blocs and withheld itself from any major decisions in the global arena. By supporting China during its independence and advocating the slogan "Asia for Asians", India developed very cordial relations with China, and voted for China's permanent seat in the United Nations. The foreign policy of India under Nehru, who was an active Non-Alignment supporter and friends with Tito (Yugoslavia), Nasser (Egypt), Sukarno (Indonesia) and Nkrumah (Ghana), was based on the concept of non-interference and nonaggression. The Non-Alignment leaders disapproved of the bi-polar world structure led by the US and USSR and supported a multipolar world system. Being totally against the system of alliances and blocs, they based their movement on the principles of sovereignty and independence. Nehru's policy ran counter to US interests [2]. With the emergence of new communist state People's Republic of China in 1949 and the beginning of the Korean War, the US policies towards the Asian region had changed. The worth of India in the global arena had grown and, due to its ideological and geopolitical importance in Asia, the US recognized the new state as a prospective partner to countervail communist China and USSR [2]. But America's plans fell through, as India decided to stick to its non-alignment status. To shift the global power balance in its favor, the US formed a containment alliance with other Asian countries. For several weeks at the beginning of 1951, the level of Indo-US distrust remained extremely high. When the US rejected the peace resolution, Nehru took a stand against the US and supported China with the motto "Asia for Asians" purporting that western powers have no right to interfere in the internal affairs of Asian countries as they are quite capable of managing their own public order [1].

In the context of Indian nuclear development in the pre-Cold War era, the British government established Tata Institute of Fundamental Research in Mumbai. The institute was headed by Homi Bhabha, who was the executive of Indian Atomic Energy Committee at that time. Nehru supported the Committee and explained that "the rationale of Indian atomic energy is only for peaceful means". After the British pressured India into joining the commonwealth and giving up "fake loyalties" (implying its possible alliance with the USA), Washington was seriously confused as to who its allies in South Asia were and was set on monitoring Indian nuclear developments. A month later, Assistant Secretary of State for Near Eastern Affairs George C. McGhee came to South Asia to explain the American policy of invasion in Tibet and Korea. The 1952 elections in America ended 
with a landslide victory of Dwight D. Eisenhower, and Republicans took over both houses of Congress. The Eisenhower administration sent Secretary of State Dulles to South Asia, and in the same year he visited India after his visit to Karachi [3].

In the mid-fifties, paradoxically, the US was able to build cordial relations with two rivaling South Asian states - India and Pakistan, trying to ally itself with both. After when the US declared Washington Pact with Pakistan, Nehru categorically denounced America's double game, saying that the ultimate purpose behind the US amiability was to create a counter force to contain its communist enemies and establish hegemony in the Asian region. In 1954, the Indian leaders condemned US "Massive Retaliation" policy, in which America committed itself to retaliate by using its nuclear arsenals in the event of an attack from an aggressor. Meanwhile, in 1954, India concluded a treaty with China in regard to Tibet, recognizing it as autonomous part of China. Furthermore, China and India did not get involved in the Korean War and signed the Panchsheel treaty. Nehru emphasized that "peace in the Asia is necessary and could not be promoted without friendly relations with China". Subsequently, Chinese premier Mr. Zhou Enlai flew to India to consult with Nehru, where he received a very warm welcome from the Indian leader. As a result of the meeting, the leaders agreed on five principles:

- Respect for territory and sovereignty.

- Non-aggression.

- Non-interference in domestic affairs.

- Equality and mutual benefit.

- Peaceful co-existence.

Upon signing the treaty, Nehru immediately made Panchsheel the touchstone of Indian foreign policy and expressed his desire for these principles to be applied at the international level. At the 1955 Bandung Conference of Asia, Nehru announced that "now "Panchsheel" is the basis of Indo-China friendly relations and in the context of these principles we will settle any distrust in future".

Against the backdrop of Nehru's Non-Alignment stance, critical attitude towards America's policy and India's teaming up with China, the Indo-US relations took an unfavorable turn [4]. As a result of which, Iraq, Turkey, Iran, Pakistan, Britain and the US signed the Baghdad pact, and Pakistan, US and Taiwan established the SEATO. As the US kept signing treaties with other countries (Japan, South Korea and New Zealand), its main goals remained to create a counter balance for the communist bloc, establish its hegemony in the world and prevent India from allying with communist countries. Nonetheless, India held on to the Panchsheel principles, and the catchphrase "Hindi-Chini, Bhai-Bhai" ("Indians and Chinese are brothers") became the core of China-India relations in the 1950s. Nehru called the Chinese leader as a "younger brother", to which Zhou responded: "I have met all the preeminent leaders of the world, but I have never met anyone more arrogant than Mr. Nehru". The Sino-India friendly relations were a heavy blow for the US leadership, as they realized the possibility of India joining the Communist bloc in future. However, when in 1962 the Tibet issue broke out, 
Sino-India relations shipwrecked: China attacked India, and for next 14 years the diplomatic relations between the countries were non-existent. That was the turning point for the creation of the Indo-US potent nexus, as India got full military and economic support from the US against China. Nehru expressed his frustration with the situation: "China is a great and powerful country with enormous resources, but India is not weak and won't be frightened by threats and military might". Americans equipped Indian troops with B-47 bombers and sent military advisors and technicians to India [5].

Thus, besides holding the trump card of India's obligation for full military and economic support in its confrontation with China, the US also criticized the USSR on its engagement in Cuba. On December 19, when the USSR withdrew from Cuba, China also decided to put an end to the Indo-Chinese war and solve the border dispute by peaceful means. After the war, the Indo-US friendly relations were formally established, however, India was still officially involved in the Non-Alignment movement and did not join any powerful blocs [3]. When the 1965 Indo-Pak war started, the India-US relations were not yet fully developed. Naturally, the US supported its ally Pakistan, both militarily and politically (including during the UN forum), and tensions between the two democracies (US and India) were once again created. The anxious Indian leadership turned to the US with a demand to stop military assistance to Pakistan, which was used by Pakistan against India. Despite of the US support to India in the Indo-China war, India did not leave the Non-Alignment movement and point-blank refused to support American anti-communism policies [6].

The 1965 Indo-Pak war put the US loyalties to test: on the one hand, Pakistan had been America's long-standing and trustworthy ally, and on the other hand, Washington was interested in creating a strong partnership with India. From 1954 to early December 1965, the US rendered aid to India under the provision of Agricultural Trade Development and Assistance Act 'PL-480'. The program opened new market opportunities for American products, while 'PL-480' brought about a fundamental change in the direction of Indian economy. The Indian government announced a new farm program, as 1.5 million tons of American wheat was imported to India [7].

\section{The 1970s Relations}

By the early 1970s, the rapport between the US and China had been established, facilitated by a number of global changes, such as the policy of détente, Cultural Revolution (1966-1969) in China, as well as normalization of the US and China relations with Pakistan, which played a crucial role in the Indo-American partnership. On the other hand, India fell victim to Nixon and Kissinger's triangular diplomacy and got tangled in the Washington-Moscow-Beijing relations. Kissinger's visit to Beijing in an attempt to build bridges of friendship, as well as Pakistan's strategic relationship with China, struck a warning note for to India [8]. As the American leadership abolished their policy of containment, the goal of the 
new diplomacy was to manage relations between two contesting communist powers - China and the USSR. In addition, American president Nixon played a double game: while he used Pakistani president Agha Yahya Khan to fix US relations with China, thus creating a threat to India with the possible US-China-Pakistan nexus, he also pitted China and the USSR against each other. Washington's attempt to mend fences was eagerly welcomed by Beijing. Nixon announced that he would travel to China in order to establish a good rapport between the two countries and eliminate any past mistrust [5].

To sum up, the India-US relationship reached its lowest point on the threshold of the Indo-Pakistan war of 1971. The US supported Pakistan and India slammed the American actions as an underhanded act of aggression. In August 1971, Indira Gandhi signed the Peace, Friendship and Cooperation treaty with the USSR to counteract a possible US-China-Pakistan alliance against India. The reciprocal agreement specified strategic cooperation in the event of a military attack in the course of the following 25 years [9]. The Indian forces were engaged in military operations in East Pakistan in 1971, which led to the defeat of the Pakistani army and emergence of one more sovereign state - Bangladesh. Whereas, Indira Gandhi was nicknamed "Iron Lady" for her deft actions that led to the victory in the India-Pak war and aggressiveness towards the US. Nixon and Kissinger not only misestimated the crisis in East Pakistan, their conscious pro-Pakistani bias turned a regional conflict into a major global conflagration, which resulted in Indian inclination towards the Soviet camp, reinforced by the India-USSR friendship treaty. India became a principal ally of the Soviet Union, and the USSR fully supported India not only from the military and economic perspectives, but also on the Kashmir issue and UNSC. In return, India backed up the Soviets on the 1979 Afghanistan invasion [3].

During 1972, the Nixon administration faced an aggressive and negative attitude from the Indian leaders triggered by American support of Pakistan. In May, the US and USSR signed the agreement on chief documents ("The Basic Principles of Relations") concerning U.S.-Soviet bilateral relations and held two rounds of conferences ('Salt 1' and 'Salt 2') to prevent the proliferation of weapons of mass destruction. Following the bilateral talks, the US managed to build durable relations with the Soviets, China and Pakistan. India, however, was left on the sideline. Thus, as perceived by the Indian leadership, the US replaced the bipolar world structure with a triangular one, this time including China. The strengthening US-Sino-USSR relations raised a red flag with India, who was weary of a possible security threat from China [1]. In 1973-1974, by virtue of Kissinger and Nixon's efforts, and as a consequence of bilateral negotiations to reach mutual understanding and support, the India-US relations were stabilized. Again, in 1975, the IndoUS partnership showed signs of strain, when the US imposed a ten-year embargo on the sale of lethal arms to South Asia, after which Indian cancelled all scheduled visits. In 1977, after the formation of Janata Government in India, the IndiaUS relations made some progress. In 1978, Jimmy Carter visited India, which was followed by a return visit from Indian Prime Minister Morarji Desai. Meanwhile, 
Nixon visited Beijing with the purpose of consolidating a partnership with China. Consequently, China got a permanent seat in the UNSC, which was unacceptable for India [10].

In the meantime, the US was playing a very careful chess game in Asia, building friendly relations with all major regional players. In December 1978, the US and China signed an agreement, in which the US consented to withdraw from Taiwan and formally recognize the Beijing government as the legitimate government of China. The main obstacle in the way of normalization of the Sino-US relations was the Taiwan issue, as China was angered by the USA sponsoring Taiwan with armaments, which was thought to be a great threat to its national security and peace. Other issues, such as the US invasion in Grenada and America's willingness to participate in the arms race, also became a stumbling-block on the way to the Sino-US good rapport. Eventually, the differences were ironed out against the backdrop of the mutually beneficial economic partnership, and the US became China's third largest trading partner. However, the two countries never completely got over the past rivalries [7].

\section{The 1980s Relations}

In 1981, the US and China reinforced their relations with a number of agreements in the fields of trade, civil aviation, maritime traffic, textiles, and commerce. However, China remained apprehensive about US-Taiwan relations, remembering American support to Taiwan in the China-Thai war. According to China, despite officially supporting the 'one China policy', the US upgraded the aircrafts it was sending to Taiwan. Besides that, Washington maintained semicordial relations with India. However, when the Soviet Union invaded Afghanistan in 1979, the global settings completely changed and the world found itself at sixes and sevens. The invasion was a flat-out threat for American hegemony in the Asian region, therefore, the US supported Pakistan in terms of military and economic needs, supplying the "freedom fighters" with ammunition and provision. For all intents and purposes, it was a proxy war fought by Pakistan on behalf of the US against the USSR. The Indian leaders, displeased with the US presence in the Indian Ocean, officially declared that the US used Pakistan and its fighters to pursue its interests in the confrontation with the Soviet Union. The American leadership commented their objective was to contain the spread of communism in South Asia [10].

Between 1982 and 1985, Indian Prime Ministers Indira Gandhi and Rajiv Gandhi paid visits to the US in an attempt to restore friendly ties between India and the US; as a result, a cooperation initiative in the fields of security, science and technology was launched. In 1985, the high officials of both countries continued to pay each other visits in order to consolidate the cooperation. The USA was not the only country India tried to repair the strained relations with: in 1988, Rajiv Gandhi visited Beijing to solve the border dispute, and eliminate the mistrust be- 
tween the two nations. In 1991, thirty-one years after his last visit, Li Pang travelled to India with the aim to establish strong diplomatic relations [11].

As the US took a positive stance on preventing nuclear proliferation, India (and later Pakistan) became the centerpiece of its non-proliferation efforts. According to India, the Nuclear Non-Proliferation Act, the Pressler Amendment, and Symington Amendment, as well as supply of F-16 aircrafts and weapons to Pakistan in the American proxy war in Afghanistan, created an unlevelled playing field for India and Pakistan and fueled the arms race in the subcontinent. Under these circumstances, the downfall of the USSR led to an unfortunate (if not catastrophic) development in New Delhi. The disintegration of the Soviet Republics forced India (needing a new powerful and reliable ally) to reconsider its foreign policy towards its neighboring rival states - China and Pakistan. As Gorbachev's reforms in 1991 led to the collapse of the USSR and the failure of its version of Communism, the Cold War came to an end, and so did the fifty-year-long turmoil in the history of the Indo-US relations. The USA remained the sole superpower, with its democratic ideology triumphing over Marxist Communism [2].

\section{Relations in the Post-Cold War Decade: the 90s Era}

After the end of the Cold War, the US reshaped its policies towards the Asian region and declared the new world order. Washington developed an inclusive economic, military and political partnership with India, and the relations between the two democracies transformed from "estrangement" to "engagement". In the context of the improving economic relations with India, the US committed to providing developmental and provision assistance to South Asia. By 2000, India received $\$ 170$ million in the form of humanitarian aid [12], which was 45 times larger than the relief support to Pakistan. India and the US now have a shared interest in stability in the Indian Ocean region and in maintaining an adequate balance of power in Asia.

India is a relatively large, economically and militarily sufficient country. Provided the Indian government carries through with its economic reforms, genuinely modifying India's economic policies in order to open the country for the rest of the world and inlock new market opportunities, the US is unlikely to get more economically involved with India than it has in the past [13].

The post-Cold War era marked the beginning of a new chapter in the relations between India and the United States, as they transformed from estrangement to engagement. There were many political, economic and strategic factors behind this change. Firstly, "the world's fate will be decided in the Indian Ocean. Whoever controls the Indian Ocean, controls Asia, because this ocean is the key to the seven seas" [10]. The importance of the Indian Ocean is related to the US policies of European-Atlantic and Asia-Pacific, which brought the US closer to India, whose role in the development of the US policies may become vital. Beijing riposted to the US activities in the Indian Ocean in a very sagacious manner and adopted the "periphery" and "strings of pearls" strategies to secure itself in the In- 
dian Ocean region. China's counter-strike ran contrary to the US plans to establish hegemony in the South Asian region and its periphery and decrease Chinese influence in the region.

Secondly, the Asia Pacific region has the largest energy reserves in the world. Chinese military modernization in Asia Pacific directly threatens the US dominance and Indian interests in the region.

Thirdly, the US has been trying to strengthen its presence in South Asia through joint military exercises with India and enjoying "the freedom of the maritime lanes from the Hormuz Straits and branching out in the West and East" [10].

Fourthly, due to China's economic escalation and expansion of its armed forces, the US has re-examined its policy towards India. Owing to its rising economic and nuclear power, as well as strategic potential that can be used to counter China, India became momentous for the US policy makers.

In the fifth place, the US realized the importance of India as a counterweight to rising China, capable of contributing to the re-distribution of power in the Asian arena. Using the former tensions between India and China caused by the border disputes and historical resentment (the two nations were historical competitors from economic, political and strategic perspectives), the USA is trying to use the power rebalance in its favor. Three "transition states" - Russia, China and India - are political players that need to be "handled with care" by the US. Rapprochement with India to contain China was the best option for Washington to prevent a possible China-India-Russia alliance.

In the sixth place, India has shown itself as an important commercial partner with a rapid economic growth and notable development in the information technology industry.

In the seventh place, after the disintegration of the Socialist bloc, China is currently the most influential and fastest growing power in Asia. Its rapid expansion in Asia Pacific has turned it into the number one competitor of the United States.

And lastly, the US adopted the "balance of power" strategy, using India as a countervailing force against rising China [10].

\section{REFERENCES}

[1] Buckley R. The United States in the Asia-Pacific since 1945. Cambridge University Press; 2002. 258 p.

[2] Sinha R. Sino-American Relations: Mutual Paranoia. Palgrave Macmillan UK; 2003. $255 \mathrm{p}$.

[3] Brands H.W. India and the United States: The Cold Peace. Twayne Pub; 1990. 195 p.

[4] Cohen S.P. India: Emerging Power. Brookings Institution Press; 2004. 377 p.

[5] Nathan A.J., Gilley B. China's New Rulers: The Secret Files. New York Review of Books; 2003. $280 \mathrm{p}$.

[6] Harinder S. New Directions in India-US Relations. The New Asian Power Dynamic. New Delhi: Sage Publications; 2006. DOI: http://dx.doi.org/10.4135/ 9788132101352.n7 
[7] Aijazuddin F.S. From a Head, Through a Head to a Head: The Secret Channel Between the US and China Through Pakistan. Oxford University Press, USA; 2000. 163 p.

[8] Mohan C.R. Crossing the Rubicon: The shaping of India's New Foreign Policy. New Delhi: Viking; 2003. 352 p.

[9] Kumar S. India's International Relations. New Delhi: Maeford Publishers; 2006. 320 p.

[10] Chopra V.D. ed. India's Foreign Policy in the 21st Century. Gyan Publishing House; 2006. 328 p.

[11] McMahon R.J. The Cold War on the Periphery: The United States, India, and Pakistan. NY: Columbia University Press; 1994. 432 p.

[12] Sharma S.D. China and India in the Age of Globalization. Cambridge University Press; 2009. $336 \mathrm{p}$.

[13] Cameron F. US Foreign Policy after the Cold War: Global Hegemon or Reluctant Sheriff? Routledge; 2006. 236 p.

Научная статья

\title{
Американо-индийские отношения через призму холодной войны: период отчуждения (краткий обзор)
}

\author{
Р.Д. Нисар \\ Классический университет центрального Китая \\ № 152, Люою Роад, Ухань, Хубэй, КНР, 430079
}

Аннотация. В данной статье дается краткое описание непростой истории отношений, идеологических разногласий, расхождений в национальных интересах, непонимания, взлетов и падений в отношениях между двумя крупнейшими демократиями - Индией и США - в период холодной войны. После Второй мировой войны между двумя конкурирующими сверхдержавами - США и СССР - началось идеологическое противостояние, получившее название «холодной войны». В эпоху холодной войны оба государства стремились распространить свои идеологии на азиатский регион и его периферию. США формировали блоки безопасности и оказывали существенную финансовую помощь азиатским странам в попытке сдержать экспансию коммунистической идеологии своего главного соперника (СССР) в регионе. После обретения Индией независимости США оказали давление на индийское руководство, чтобы оно присоединилось к американскому блоку против Советского Союза. С другой стороны, СССР coздал Варшавский договор и пытался включить в свой блок вновь рожденные государства, такие как Индия и Пакистан, чтобы противостоять курсу США. Однако Индия не была настроена вступать в какие-либо внешние блоки, прежде всего в блок США, и вступила в Движение неприсоединения. Автор отмечает, что вместо заключения внешнеполитических альянсов индийское руководство поддержало лозунг «Азия для азиатов» и осудило участие внерегиональных держав, таких как США, в азиатских региональных делах.

Ключевые слова: холодная война, Индо-американские отношения, Движение за Индию и неприсоединение, политика сдерживания США 


\section{Информация об авторе:}

Рана Даниш Нисар - аспирант Школы политики и международных исследований Классического университета центрального Китая (KHP) (ORCID ID: 0000-0002-13545144) (e-mail: ranadanishnisar@gmail.com).

\section{Information about the author:}

Rana Danish Nisar - PhD Student of the School of Politics and International Studies, Central China Normal University (People's Republic of China) (ORCID ID: 0000-00021354-5144) (e-mail: ranadanishnisar@gmail.com).

\section{Для цитирования:}

Nisar R.D. India-US Relations Through the Lens of Cold War: The Time of Estranged Relations (Brief Overview) // Вестник Российского университета дружбы народов. Серия: Государственное и муниципальное управление. 2019. Т. 6. № 4. С. 286-295. DOI: 10.22363/2312-8313-2019-6-4-286-295

\section{For citation:}

Nisar R.D. India-US Relations Through the Lens of Cold War: The Time of Estranged Relations (Brief Overview). RUDN Journal of Public Administration. 2019; 6 (4): 286-295. DOI: 10.22363/2312-8313-2019-6-4-286-295 